\title{
The Westphalian Legal Orthodoxy - Myth or Reality?
}

\section{Stéphane Beaulac*}

\section{Introduction}

In public international law, there may not be a greater orthodoxy than that according to which the Peace of Westphalia in 1648, which ended the Thirty Years War in Europe, constitutes a paradigm shift in the development of our state system. ${ }^{1}$ The twin congress then held is deemed the forum where distinct separate polities became sovereign, that is, enjoying absolute and exclusive control and power over a relatively well-defined territory. ${ }^{2}$ it is portrayed as a historical fact ${ }^{3}$ that Westphalia "represented a new

* Legal Scholar and Ph.D. Candidate in International Law (Cantab), LL.M. in Comparative Law (Cantab), Diploma in Legislative Drafting (Ottawa), LL.B. in Common Law (Dalhousie), and LL.L. in Civil Law (Ottawa).

${ }^{3}$ See, among numerous international legal commentators who take that position or assume its validity, S. Baker (ed.), Halleck's International Law - Rules Regulating the Intercourse of States in Peace and War, 2nd ed., vol. 1 (London: Kegan Paul, 1878), at 13-14; A.D. McNair (ed.), L.F.L. Oppenheim ‥ International Law, 4th ed., vol. I (London: Longmans, Green, 1928), at 6970; M. Sibert, Traité de droit international public, vol. 1, Le droit de la paix (Paris: Dalloz, 1951), at 48; J.G. Starke, An Introduction to International Law, 5th ed. (London: Butterworths, 1963), at 10; H. Waldock (Ed), J.L. Brierly ... The Law of Nations, 6th ed. (Oxford: Clarendon Press, 1963), at 5-6; and, P. Daillier \& A. Pellet (eds.), Nguyen Quoc Dinh … Droit international public, 5 th ed. (Paris: Librairie générale de droit et de jurisprudence, 1994), at 50.

${ }^{2}$ For a historical analysis of the concept of sovereignty, which includes the seminal contributions of Bodin and Hobbes - its first two architects - see F. H. Hinsley, Sovereignty, 2nd ed. (Cambridge: Cambridge University Press, 1986). He wrote, at 25-26: "[A]t the beginning, at any rate, the idea of sovereignty was the idea that there is a final and absolute political authority in the political community; and everything that needs to be added to complete the definition is added if this statement is continued in the following words: 'and no final and absolute authority exists elsewhere." [emphasis in original]

: On the pitfalls and virtues of history in social sciences, see generally P. Winch, The Idea of a Social Science and its Relations to Philosophy (London: Routledge, 1958), at $181 \mathrm{ff}$; and, in the context of international law, see P. Allott, "International Law and the Idea of History" (1999), I J. History Int'l L. 1.

As regards the subjectivity of one's idea of history, or the so-called hermeneutic puzzle, see R.G. Collingwood, The Idea of History (Oxford: Clarendon Press, 1946), at 218, who wrote: "Historical knowledge is the knowledge of what mind has done in the past, and at the same time it is the redoing of this, the perpetuation of past acts into the present. [...] To the historian, the

Journal of the History of International Law 2: 148-177, 2000. (C2000 Kluwer Law International. Printed in the Netherlands. 
diplomatic arrangement - an order created by states, for states - and replaced most of the legal vestiges of hierarchy, at the pinnacle of which were the Pope and the Holy Roman Emperor."4

In his essay marking the tercentenary of the Peace, Leo Gross emphasised how much 1648 constituted a turning point in the organisation of Europe, away from the socalled ancien régime. He wrote: "Westphalia, for better or worse, marks the end of an epoch and the opening of another. It represents the majestic portal which leads from the old into the new world." It is said to have consecrated the principle of sovereign equality of $\operatorname{states}^{6}$ which, since then, has been at the core of international law. ${ }^{7}$ The

activities whose history he is studying are not spectacles to be watched, but experiences to be lived through in his own mind; they are objective, or known to him, only because they are also subjective, or activities of his own." [emphasis added]

${ }^{4}$ K.J. Holsti, Peace and War $\cdots$ Armed Conflicts and International Order; 1648 - 1989 (Cambridge: Cambridge University Press, 1991), at 25. [footnotes omitted]

"L. Gross, "The Peace of Westphalia 1648-1948"(1948), 42 American J. Int'l L. 20, at 28. Later, at 28-29, he wrote: "In the spiritual field the Treaty of Westphalia was said to be "a public act of disregard of the international authority of the Papacy. 'In the political field it marked man's abandonment of the idea of a hierarchical structure of society and his option for a new system characterized by the coexistence of a multiplicity of states, each sovereign within its territory, equal to one another, and free from any external earthly authority;" [footnotes omitted] [emphasis added] Unequivocally, C.S. Rhyne, International Law - The Substance, Processes, Procedures and Institutions for World Peace with Justice (Washington: CLB Publishers, 1971), at 9, wrote: "The traditional European international law system dates from the Treaty of Westphalia of 1648 , which marked the formal recognition of states as sovereign and independent political units."

${ }^{6}$ The Charter of the United Nations, 26 June 1945, TS no. 993, 145 UKTS 805, Can TS no. 7, reproduced in M.D. Evans (ed.), Blackstone's International Law Documents, 3rd ed. (London: Blackstone Press, 1996), 8, states as its first principle, in article 2: "The Organization is based on the principle of the sovereign equality of all its Members." See also I. Brownlie, Principles of Public International Law, 4th ed. (Oxford: Clarendon Press, 1990), at 287, who wrote: "The sovereignty and equality of states represent the basic constitutional doctrine of the law of nations, which governs a community consisting primarily of states having a uniform legal personality."

${ }^{7}$ Similarly, in other disciplines, Westphalia is considered "the cornerstone of the modern system of international relations;" see G. Poggi, The Development of the Modern State - A Sociological Introduction (London: Hutchinson, 1978), at 89. One of the first advocates of the realist school of international relations, H.J. Morgenthau, Politics Among Nations - The Siruggle for Power and Peace, 3rd ed. (New York: Knopf, 1963), at 312, wrote: "By the end of the Thirty Years' War [1648], sovereignty as supreme power over a certain territory was a political fact, signifying the victory of the territorial princes over the universal authority of emperor and pope, on the one hand, and over the particularistic aspirations of the feudal barons, on the other."

See also, among many contemporaries who share that position R. Jackson, "Sovereignty in World Politics: A Glance at the Conceptual and Historical Landscape" (1999), 47 Political St. 
publicist Charles Fenwick once wrote that after the Peace, "the international community was to consist of coequal members individually independent of any higher authority."

Is the Westphalian legal orthodoxy myth ${ }^{9}$ or reality? The hypothesis of this paper is that, contrary to the overwhelmingly accepted view, ${ }^{10} 1648$ does not close the final

431; D. Philpott, "Ideas and the Evolution of Sovereignty," in S.H. Hashmi (ed.), State Sovereignty ... Change and Persistence in International Relations (Pennsylvania, U.S.: Pennsylvania State University Press, 1997), 15; and, J. Rosenberg, The Empire of Civil Society $\cdots$ A Critique of the Realist Theory of International Relations (London \& New York: Verso, 1994), at 138, who wrote: "An absolutist states-system was initialled at Westphalia." Contra, see S.D. Krasner, "Westphalia and All That," in J. Goldstein \& R.O. Keohane (ed.), Ideas and Foreign Policy .. Beliefs, Institutions, and Political Change (Ithaca, U.K.: London Cornell University Press, 1993), 235.

${ }^{8}$ C. Fenwick, International Law, 4th ed. (New York: Appleton-Century Crofts, 1965), at 14.

${ }^{9}$ Roland Barthes elaborated on the question of myth and mythology in his essay entitled "Myth Today," in R. Barthes, Mythologies (London: Vintage, 1972), 109, at 109, 111 \& 142, where he noted that "myth is a type of speech" which, as part of semiotics, "has the task of giving a historical intention a natural justification, and making contingency appear eternal." [emphasis in original] He also wrote: "The signifier of myth presents itself in an ambiguous way: it is at the same time meaning and form, full on one side and empty on the other;" $i d$., at 117 . Finally, he expressed the following view: "What is characteristic of myth? To transform a meaning into form. In other words, myth is always a language-robbery;" id., at 131. [emphasis added] See also C. Lévi-Strauss, "The Structural Study of Myth" (1955), 68 J. American Folklore 428; P. Wheelwright, "The Semantic Approach to Myth" (1955), $68 \mathrm{~J}$. American Folklore 473; and, A.W. Watts, Myth and Ritual in Christianity (London \& New York: Thames \& Hudson, 1953), at 7, who wrote: "Myth is to be defined as a complex of stories - some no doubt fact, and some fantasy - which, for various reasons, human beings regard as demonstrations of the inner meaning of the universe and of human life." For an example of an argument that a concept is mythical, in the context of nationalism and self-determination, see J. Starr, "Passionate Attachments: Reflections on Four Myths of Nationalism" (1995), 28 Indiana L. Rev. 601; and, R.T. de George, "The Myth of the Right of Collective Self-Determination," in W. Twinning (ed.), Issues on SelfDetermination (Aberdeen: Aberdeen University Press, 1991), 1.

This can be linked to the idea of fallacy, developed by Jeremy Bentham; see H.A. Larrabee (ed.), Bentham's Handbook of Political Fallacies (New York: Harper Brothers, 1962), at 3, which described the concept as follows: "By the name of fallacy it is common to designate any argument employed or topic suggested for the purpose, or with the probability of producing the effect of deception, or of causing some erroneous opinion to be entertained by any person to whose mind such an argument may have been presented."

${ }^{10}$ See supra, note 1 , for an extensive, yet non-exhaustive, list of international legal publicists supporting what is referred to as the Westphalian legal ot thodoxy. Again, recently, Professor Falk, Law in an Emerging Global Village: A Post-Westphalian Perspective (Ardsley, U.S.: Transnational Publishers, 1998), at 4, wrote: "It was not until some decades later, [after Grotius\} by way of the Peace of Westphalia in 1648 that ended the Thirty Years' War, that the modern system of states was formally established as the dominant world order framework, and it was 
chapter of the multilayered system of authority in Europe. Rather, it constitutes but one instance where distinct separate political entities strived for more power through independence, which was only achieved long after the Peace.

The following discussion will try to deconstruct ${ }^{31}$ the Westphalian model through a four-part analysis. First, the social organisation and the transcendental political entities during the Middle Ages will be considered. Second, a brief account will be given of the dynamics at work in Europe and of the events that led to the Thirty Years War. Third, the actual agreements reached in Westphalia will be examined to ascertain their main objects and material provisions, which have little to do with the creation of a state system. Finally, the post-1648 period will be considered to assess whether or not, as an aftermath of the Peace, the universal institutions disappeared in favour of distinct separate polities.

not for another century or so that it seemed possible to appreciate that indeed Westphalia had provided a defining threshold - of course, overgeneralized and simplified, but yet a convenient shorthand by which to situate the transition from the medieval to the modern." [footnotes omitted]

"The philosophical practices regarding the interpretation of texts known as deconstruction is associated with the name of Jacques Derrida, who has developed his ideas in several books, including: J. Derrida, Dissemination (London: Athlone, 1981); J. Derrida, Margins of Philosophy (Chicago: University of Chicago Press, 1982); J. Derrida, Of Grammatology (Baltimore, U.S. \& London: Johns Hopkins University Press, 1976); J. Derrida, Positions (London: Athlone, 1981); J. Derrida, Speech and Phenomena; and Other Essays on Husserl's Theory of Signs (Evanston, U.S.: Northwestern University Press, 1973); J. Derrida, Writing and Difference (Chicago: University of Chicago Press, 1978). For a general introduction to Derrida's work, see J. Culler, On Deconstruction - Theory and Criticism afier Structuralism (London: Routledge \& Kegan Paul, 1983), at $85 \mathrm{ff}$. See also J. Bartelson, A Genealogy of Sovereignty (Cambridge: Cambridge University Press, 1995), at 20, who wrote: "As an antidote to uncritical conceptual analysis, deconstruction involves a demonstration of the metaphysical or ideological character of the presuppositions relied on, and the determination of their place in a wider system of metaphysical or ideological values. Furthermore, deconstruction implies a reversal of the conceptual oppositions discovered in a text, rather than an attempt to criticise them from an allegedly external or neutral perspective."

On the deconstruction of legal concepts in general, which is incidentally linked to the socalled critical legal studies, see J.M. Balkin, "Deconstructive Practice and Legal Theory" (1986), 96 Yale L.J. 743, at 744, who noted: "Lawyers should be interested in deconstructive techniques for a least three reasons. First, deconstruction provides a method for critiquing existing legal doctrines; in particular, a deconstructive reading can show how arguments offered to support a particular rule undermine themselves, and instead, support an opposite rule. Second, deconstructive techniques can show how doctrinal arguments are informed by an disguise ideological thinking. This can be of value not only to the lawyer who seeks to reform existing institutions, but also to the legal philosopher and the legal historian. Third, deconstructive techniques offer both a new kind of interpretive strategy and a critique of conventional interpretations of legal texts." For an application of deconstructive readings in law, see C. Dalton, "An Essay in the Deconstruction of Contract Doctrine" (1985), 94 Yale L.J. 997. 


\section{Heteronomous Organisation and Transcendental Political Entities}

Following the collapse of the Western Roman Empire in 476, most territories in Europe were in a chaotic political status because of the so-called barbarian invasions. ${ }^{12}$ The separate communities constituted segmented societies characterised by a heteronomous form of organisation. ${ }^{13}$ Individuals had different rights and obligations, which could overlap and conflict since the decentralised feudal structure was not hierarchical. ${ }^{14}$ The vassalage system, which provided land in exchange for loyal services, also meant that some subordinates acquired considerable resources and corresponding power. ${ }^{15}$ Indeed, "Europe was not divided up into exclusive sovereignties, but was covered by overlapping and constantly shifting lordships." $I t$ is not until the second half of the Middle Ages, starting in the 11 th century, that some monarchs began to develop a more organised form of government. ${ }^{17}$

${ }^{12}$ See, generally, F.L. Ganshof, L'histoire des relations internationales, vol. 1, Le Moyen Âge (Paris: Hachette, 1953), at 5-9.

${ }^{33}$ Segmentation was at various stage in European communities, with pre-conquest England's decentralised governance, the Anglo-Norman Kingdom relatively integrated, the German area and its fundamental duchy divisions, and the French kingdom's theoretical centralisation; see F.H. Hinsley, supra, note 2, at 6!-62.

On heteronomous systems, see J.G. Ruggie, "Continuity and Transformation in the World Polity: Toward a Neoreatist Synthesis," in R.O. Keohane (ed.), Neorealism and its Critics (New York: Columbia University Press, 1986), 131, at 141-143. Essentially, heteronomy bases the authority of polities on the functions fulfilled, not on the territory where the authority is exercised.

${ }^{14}$ See M. Fischer, "Feudal Europe, 800-1300: Communal Discourse and Conflictual Practice" (1992), 46 Int'l Org. 427, at 449, who wrote: "[T] he legal institutions of vassalage, dependency, servitude, and fief organized feudal society into a highly heteronomous network of mutual obligations and shared rights." See also B. de Jouvenel, Sovereignty - An Inquiry Into the Political Good (Cambridge: Cambridge University Press, 1957), at 171-173; and, J.A. Camilleri, "Rethinking Sovereignty in a Shrinking, Fragmented World," in R.B.J. Walker \& S.H. Mendlovitz (eds.), Contending Sovereignties - Redefining Political Community (Bouldes, U.S. \& London: Lynne Rienner, 1990), 13, at 13.

${ }^{35}$ On the legal institution of vassalage, see F.L. Ganshof, Feudalism (London: Longmans, 1952), at 63-95; M. Bloch, Feudal Society, vol. 1, The Growth of Ties of Dependence (London \& Henley: Routledge \& Kegan Paul, 1965), at 218-230; and, J.S. Critchley, Feudalism (London: Allen \& Unwin, 1978), at 30-55.

On the power dimension of the vassalage system, see F. de Coulanges, Histoire des institutions politiques de l'ancienne France, vol. 6, Les transformations de la royauté pendant l'époque carolingienne (Paris: Hachette, 1892), at $703 \mathrm{ff}$.

${ }^{16}$ G. Clark, Early Modern Europe from about 1450 to about 1720 (London: Oxford University Press, 1957), at 28. See also J. Anderson \& S. Hall, "Absolutism and Other Ancestors," in J. Anderson (ed.), The Rise of the Modern State (Brighton, U.K.: Harvester Press, 1986), 21, at 2528.

${ }^{37}$ See, generally, J.R. Strayer, On the Medieval Origins of the Modern State (Princeton, U.S.: Princeton University Press, 1970), at 26-36; and, M. Wilks, The Problem of Sovereignty in the 
This period also saw most of these polities getting together in a common Christian community, i.e. Christendom. This spiritual union encouraged and facilitated contacts and, with the martial energy of the Crusades, was the catalyst to a profound social transformation of almost all Western Europe. ${ }^{18}$ It also brought two new powerful actors to the forefront of European politics ${ }^{19}$ - the Pope and the Emperor. Both aspired to the throne of the civitas Christiana, ${ }^{20}$ which entailed an authority superior to all other rulers. ${ }^{21}$ It has been said to constitute the "greatest attempt of all time at supranational organisation in Europe." 22 The co existence of these two transcendental political entities, however, was never peaceful and amicable.

When the Roman Empire in the West resumed in $800,{ }^{23}$ Charlemagne (also known as Karl the Great) seemed to acknowledge the Papacy's authority. ${ }^{24}$ After the Treaty of Verdun in $843,{ }^{25}$ however, the new Holy Roman Emperor began to challenge the

Later Middle Ages - The Papal Monarchy with Augustinus Triumphus and the Publicists (Cambridge: Cambridge University Press, 1963).

${ }^{18}$ See T.A. Walker, A History of the Law of Nations, vol. 1, From the Earliest Times to the Peace of Westphalia, 1648 (Cambridge: Cambridge University Press, 1899), at 87, who wrote: "The Crusades wrought a social revolution." He identified six areas where the Christendom's fight over the Holy Land infuenced the development of the European fabric. They include: (i) the shifting of baronial war effort from private combats to foreign conflicts; (ii) the creation of great centres of political power, such as the cities of Northern Italy; (iii) the increase of the authority of the Papacy, which was militant abroad but peacemaker at home; (iv) the lessons in Saracenic civilisation that the Crusaders brought back with them to the West; (v) the consolidation of the idea of Christendom unity; and (vi) the sentiment of identity that foreign involvement sparked with the people at home - see id., at 86-89.

19 See, generally, G. Schwarzenberger, A Manuel of International Law, 4th ed., vol. 1 (London: Stevens \& Sons, 1960), at 4-5.

${ }^{26}$ That is, Christian body politic.

${ }^{21}$ See M. Zimmermann, "La crise de l'organisation internationale à la fin du Moyen Âge" (1933), 44 R.C.A.D.I. 315, at 320; and, K. Pennington, "Law, Legislative Authority, and Theories of Government, 1150-1300," in 3.H. Burns (ed.), The Cambridge History of Medieval Political Thought-c. 350-c. 1450 (Cambridge: Cambridge University Press, 1988), 424, at 430-436.

${ }^{22}$ E.N. van Kleffens, "Sovereignty in International Law" (1953), 82 R.C.A.D.I. 1, at 21.

${ }^{23}$ On how the Christian Empire was considered to be the natural and rightful continuation of the Roman Empire, see J. van Kan, "Règles générales du droit de la paix - L'idée de l'organisation internationale dans ses grandes phases" (1938), 66 R.C.A.D.I. 295, at 446 ff; and, W. Ulimann, "Reflections on the Medieval Empire" (1964), 14 Transactions Royal Hist. Soc. (5th) 89, at 95-103.

${ }^{24}$ In fact, the Pope, who crowned Charlemagne, exchanged his support for the re-establishment of the Roman Empire for the recognition of the Church's authority.

${ }^{25}$ Charlemagne's only successor, Louis the Pious, died in 840 and with him the Carolingian Empire. After some years of unrest, the Treaty of Verdun divided the Empire into three parts but, given that there was only one imperium, the crown was shifted around for the first few decades. Germanic pre-eminence was finally asserted in 881 . 
universal authority of the Pope ${ }^{26}$ The latter defended himself with the two swords doctrine, ${ }^{27}$ according to which God delegated Its power over both spiritual and temporal ${ }^{28}$ spheres directly to the Papacy. ${ }^{29}$ The Emperor replied with formulas supporting his supreme secular authority over the communitas communitatum. ${ }^{30} \mathrm{He}$ could obviously not deny the divine origin of authority, but rather argued that God had equally distributed spiritual and temporal powers and that the Emperor directly received the secular sword. ${ }^{31}$ Later, under Peter Damien's influence, a period of détente was maintained by the two institutions. ${ }^{32}$

${ }^{26}$ On the struggles between the Pope and the Emperor, see J. Bryce, The Holy Roman Empire, 4th ed. (London: Macmillan, 1873), at 153-166.

${ }^{27}$ This contention was first forcefully propounded in the 11 th century by Pope Gregory VII against Emperor Henry IV. On Gregory VIl's ambitions of supremacy over both spiritual and temporal spheres, see C.H. Mcllwain. The Growth of Political Thought in the West-From the Greeks to the End of the Middle Ages (New York: Macmillan, 1932), at 217-221; and, generally, A. Fliche, Études sur la polémique religieuse à l'époque de Grégoire VII (Paris: Société française d'imprimerie et de librairie, 1916).

${ }^{28}$ The Pope's claim of supremacy over secular matters was founded on various texts of the Bible, most notably on the Gospel according to Matthew which, at chapter 16, verse 19, quotes Jesus Christ saying: "I will give you the keys to the kingdom of heaven; whatever you bind on earth will be bound in heaven, and whatever you loose on earth will be loosed in heaven." This statement is repeated at Saint Matthew, chapter 18, verse 18; see International Bible Society, The Holy Bible ... New International Version (Grand Rapids, U.S.: Zondervan, 1984), at 898899. See also K. Pennington, supra, note 21 , at $427 \& 433$.

${ }^{29}$ The Papal authority was legally based on the so-called dictatus papae. Theoretically, he enjoyed full universal legislative and judicial power, including to adjudicate disputes between rulers, to repudiate royal statutes or customs contrary to divine law, and even to depose monarchs guilty of mortal sins. See, generally, W. Ullmann, "A Medieval Document of Papal Theories of Government" (1946), 61 English Hist. Rev. 180; and, W. Ulmann, "Leo I and the Theme of Papal Primacy" (1960), 11 J. Theological St. (new ser.) 25. For a succinct account of the medieval "divine-right" theory of sovereignty, see also Y.R. Simon, Philosophy of Democratic Governmem (Chicago: University of Chicago Press, 1951), at 155-157.

3 That is, community of communities.

${ }^{31}$ For instance, the following "Declaration of Imperial Independence" was made by Emperor Ludwig IV in 1338: "Therefore, [...] with the counsel and assent of the Electors and other princes of the Empire, We declare that the imperial dignity and power are derived immediately from God alone; and that, by the law and ancient approved custom of the Empire, when anyone is elected Emperor or king by the imperial electors, unanimously or by majority, at once by the mere fact of election he is to be considered and entitled very King and Emperor of the Romans; [...] nor does be need the approbation, confirmation, authority or consent of the Pope or the Apostolic See or of any other person;" see R.G.D. Laffan, Select Documents of European History, vol. 1, 800-1492 (London: Methuen, 1930), at 149.

32 See "Pierre Damien," in Dictionnaire de théologie catholique, vol. 4 (Paris: Letouzey \& Ané, 1924), at 49, which summarises his doctrine as follows: "Son idéal, c'est l'existence parallèle 
In short, in the Middle Ages, the "European society would be the scene of a structuresystem struggle in two dimensions - horizontal, between Papacy and German Empire; vertical between Papacy/German Empire, on the one hand, and the countless subordinate civil societies of Europe, on the other hand." ${ }^{33}$ As far as the monarchs were concerned, the struggle for power was on two fronts: within, vis-à-vis the vassals and the people; and, without, vis-a-vis the Pope and the Emperor. ${ }^{34}$

The next section will examine the rapports between the many layers of authority in Europe and the explosive situation that led to the Thirty Years War.

\section{Dynamics and War of Religion and Politics}

The interaction of the different polities in both religious and political fields, as well as certain developments in organisation and governance, allowed monarchies to gain a leading position on the European chessboard. As it will be demonstrated, however, this slow process began several centuries before, and cumulated a century-and-a-half after, the Peace of Westphalia in 1648.

Despite continuous efforts until the 13th century to expand its authority, the Papacy was never fully recognised by some powerful monarchies in Europe. For instance, France and Spain never accepted feudal vassalage vis-à-vis the Pope; England repudiated Papal overlordship in $1366 .{ }^{35}$ Further, the Great Schism in the Christian Church (13781417) considerably weakened the authority of the Pope. ${ }^{36}$ Then, in 1517, Martin Luther

des deux pouvoirs du sacerdoce et de l'empire, chacun dans sa sphère, mais étroitement unis dans une réciprocité de services mutuels, dans une entente harmonieuse et parfaire, l'un réglant les affaires temporelles, l'autres les affaires spirituelles, l'État protégeant matériellement l'Église, 1'Église protégeant spirituellement 1'État." On the influence of Peter Damien on the Papal policies during the Gregorian age, see A. Fliche, supra, note 27, at $288 \mathrm{ff}$.

${ }^{3}$ P. Allott, "Self-Determination - Absolute Right or Social Poetry?," in C. Tomuschat (ed.), Modern Law of Self-Determination (Dordrecht, Netherlands: Martinus Nijhoff Publishers, 1993), 177 , at $184-185$.

${ }^{34}$ On this power struggle, on the one hand, between the monarchies and the people and, on the other, between the monarchies and Emperor/Pope, see G. Andrassy, "La souveraineté et la Société des nations" (1937), 61 R.C.A.D.I. 637, at 646-647.

See also, generally, P. Allott, Eunomia … New Order for a New World (Oxford: Oxford University Press, 1990), at 66, who explained the nature of the struggle of power in any type of society as follows: "Human beings and their societies are locked in a necessary struggle of the one and the many, as each empowers the other by disempowering itself, as each empowers itself by disempowering the other."

is See H. Steinberger, "Sovereignty," in R. Bernhardt (ed.), Encyclopedia of Public International Law, vol. 10, States - Responsibility of States - International Law and Municipal Law (Amsterdam: North-Holland, 1987), 397, at 398.

${ }^{36}$ Before the Council of Constance, which ended the Great Schism in 1417, several popes claimed to be the legitimate representant of the Papacy. Shortly after, the Council of Basle in 1449 abandoned the efforts to regain the unity of the Chistian Church through conciliar means. See J. Canning, A History of Medieval Political Thought $\cdots 300-1450$ (London \& New York: Routledge, 
nailed his 95 theses to the door of the Schlosskirche in Wittenberg, setting in motion the forces of the Reformation. His ideas, and those of John Calvin, spread rapidly throughout the numerous German principalities, as well as to Sweden, the Netherlands, France and England. ${ }^{37}$ Their political tenets, which favoured secular governance, constituted the coup de grâce for the Papal plenitudo potestatis. ${ }^{38}$

With respect to the Holy Roman Empire, no overall authority was ever fully secured in Europe. In fact, even before the Great Interregnum (1254-1273), the character and the scope of Imperial power began to be challenged. By the 14th century, authority over secular matters ceased to be considered the exclusive privilege of the Emperor. ${ }^{39}$ His de jure overlordship remained - even invigorated under Charles $\mathrm{V}$ - but legists

1996), at 176-184; and, M. Wight, Systems of States (Leicester, U.K.: Leicester University Press, 1977), at 131-133.

See also K.C. Cole, "The Theory of the State as a Sovereign Juristic Person," in W.J. Stankiewicz (ed.), In Defense of Sovereignty (New York: Oxford University Press, 1969), 86, at 88, who noted: "When, finally, the schism within the religious community occurred, it became evident that the old order was doomed."

${ }^{37}$ See, generally, M. Boegner, "L’influence de la Réforme sur le développement du droit international" (1925), 6 R.C.A.D.I. 241. Lutheran theology was based on the following principles: sola fide (faith alone), sola gratia (grace alone), sola scriptura (scripture alone), and soli deo gloria (to God alone be the glory); see D. Philpott, supra, note 7, at 30-31. See also J.B. Elshtain, Women and War (Brighton, U.K.: Harvester Press, 1987), at 136, who wrote: "Luther prepares the way for the political theology that underlies the emergence of the nation-state."

Certainly the most notorious case of Monarchial protestant disengagement from the authority of the Papacy was that of King Henry VIII of England who used the Pope's refusal to grant an annulment for his marriage to Catherine of Aragon as a political justification to elevate himself to Supreme Head of the Church of England - thus acquiring spiritual authority in addition to political power - through the Act of Supremacy, 1534; see N. Davies, Europe -. A History (London \& New York: Oxford University Press, 1996), at 490.

${ }^{38}$ That is, fullness of power. At that time, Francisco de Vitoria (also spelt Francisci a Victoria) notoriously argued against the Pope's claim of temporal jurisdiction above all princes in the first two lectures of his colfection of thirteen Relectiones, first published in 1557 - see F. de Vitoria, Relectiones Theologicae Tredecim Partibus (Lugduni: Petri Landry, 1587), at 1 ff. \& 60 ff. Likewise, in the fifth essay, dealing with the Spanish authority over the Indians in the new world, the great professor of Salamanca University expressed his unequjvocal view that the Pope was not the temporal master of the world - see $i d$, at $164 \mathrm{ff}$; see also the French translation by M. Barbier, Leçons sur les Indiens et sur le droit de la guerre (Geneva: Librairie Droz, 1966), at $46 . \mathrm{ff}$.

${ }^{39}$ See K. Pennington, supra, note 21 , at 432-433; and, T.A. Walker, supra, note 18 , at 90 , who wrote: "The Empire and the Pontiff had alike failed to fulfil their mission. The Emperor at no time fully responded to his call. Endowed with an unique style, held the natural protector and leader of Christendom, Divine Viceregent in things temporal, the rightful source of the royal title, the convoker, at least concurrently with the Pope, of oecumenical councils, he failed to constitute himself international arbiter and pacificator mundi." [footnote omitted] 
like Bartolus admitted that principes superiores non recognoscentes ${ }^{40}$ Baldus formulated this plurality in terms of rex in regno suo est imperator regni sui. ${ }^{4}$ The imperium's dismissal was more categorical in certain areas: Spain never formally recognised Imperial power; France severed its feudal ties with the Emperor after 973; and, England's vassalage vis-à-vis the Empire was terminated in the 13 th century. ${ }^{42}$

However, it seems to be the consolidation of power under autonomous rulers in England and France, as well as the emergence of free cities in Northern Italy, that effectively replaced the universal Christendom ideal with the concept of distinct separate polities. ${ }^{43}$ Chronologically, the cities of the Italian peninsula - Genoa, Florence, Pisa and Venice - were the pioneers in reaching a certain system of organisation in the 11 th and 12 th centuries, which fell within the general enthusiasm of the Renaissance. ${ }^{44}$ The querelles between the Pope and the Emperor considerably help the establishment and survival of these relatively self-sufficient polities. ${ }^{45}$ At the beginning of the 14 th century, it was recognised that the Northern Italian cities could not be conquered. By the 16 th century, however, their strength comparatively decreased because of their opponents' enhanced military capacity and the change in trade routes. ${ }^{\text {th }}$

England was the first large geographic area to reach some kind of centralised governance. Following the Great Conquest in 1066, the English segmented societies embarked upon the process towards unity. ${ }^{47}$ With the help of several institutions -

40 That is, princes do not acknowledge any superior. Other legists of the time included William of Occam, Marsiglio of Padua and Dante.

${ }^{41}$ That is, a king in his own kingdom is emperor of his realm. On this doctrine in general, see W. Ulman, "The Development of the Medieval Idea of Sovereignty" (1949), 64 English Hist. Rev. 1 , at 5-7.

${ }^{42}$ See H. Steinberger, supra, note 35, at 398. Also worth noting is that Francisco de Vitoria's lecture on the Spanish authority over the Indians in the new world demonstrated that, no more than the Pope, the Emperor was not the master of the whole world according to neither natural, divine or human law - see F. de Vitoria, supra, note 38 , at $164 \mathrm{ff}$; and, M. Barbier, supra, note 38 , at $36 f f$.

${ }^{43}$ On the authority enjoyed by the ruters of France, England and the Italian free cities, see E.N. van Kleffens, supra, note 22, at 22-25.

${ }^{4}$ See, generally, P.M. Hohenberg \& L.H. Lees, The Making of Urban Europe, 1000-1950 (Cambridge, U.S.: Harvard University Press, 1985), at 59-73; G. Mattingly, Renaissance Diplomacy (London: Johathan Cope, 1955), at 55-63; and, J. Burckhardt, The Civilization of the Renaissance in ltaly - An Essay, 2nd ed. (London: Phaidon Press, 1945), at $39 \mathrm{ff}$.

${ }^{45}$ See A.P. Sereni, The Italian Conception of International Law (New York: Columbia University Press, 1943), at 7-9.

46 See T.A. Walker, supra, note 18, at 139; and, C. Tilly, Coercion, Capital, and European States, A.D. 990-1990 (Oxford: Basil Blackwell, 1990), at 64-66.

${ }^{47}$ See J.R. Strayer, supra, note 17, at 36-48; and, R. Lansing, Notes on Sovereignty -.. From the Standpoint of the State and of the World (Washington: Carnegie Endowment for International Peace, 1921), at 16-18. 
especially the King's courts based on the common law ${ }^{48}$ - the loyalty of the people moved from the local authorities to the monarchy. ${ }^{49}$ The aristocracy-initiated movement of protest that led to the Magna Carta in 1215 did not challenge the centralised institutions per se; rather, it sought some basic guarantees of protection from the King, especially with regard to property rights. ${ }^{50}$ Although the unity of the English royal power was later shattered by the War of the Roses, it remained relatively independent from any higher authority. ${ }^{51}$

The French communities proceeded more slowly towards the organisation of central ruling under the authority of the monarch. ${ }^{52}$ Centralisation was accomplished only gradually by the appointment of the King's representatives in the provinces, instead of being imposed from above by the royal administration, as in England. ${ }^{53}$ France's judiciary did not even apply uniform laws ${ }^{54}$ - the South constituted the pays de droit écrit $t^{55}$ and the North was considered the pays de droit coutumier. ${ }^{56}$ The Hundred Years War with England increased the King's power within his territory: the great vassals

${ }^{48}$ See, generally, K. Zweigert \& H. Kötz, An Introduction to Comparative Law, 3rd ed. (Oxford: Clarendon Press, 1998), at 182 187.

4) See S.D. Krasner, supra, note 7, at 254.

${ }^{5}$ Indeed, several provisions of the Magna Carta had nothing to do with fundamental rights or civil liberties, but related directly or indirectly to property rights that the barons wanted to shield from the monarch's arbitrary power. For instance, article 9 provided: "Neither we nor our bailiffs will seize any land or rent in payment of a debt so long as the chattels of the debtor are sufficient to repay the debt; nor shatl the sureties of the debtor be distrined so long as the debtor himself is capable of paying the debt, and if the principal debtor defaults in the payment of the debt, having nothing wherewith to pay it, the sureties shall be answerable for the debt; and, if they wish, they may have the lands and revenues of the debtor until they have received satisfaction for the debt they paid on his behalf, untess the principal debtor shows that he has discharged his obligations to the sureties." Similarly, article 27 states: "If any free man dies intestate, his chattels are to be distributed by his nearest relations and friends, under the supervision of the Church, saving to everyone the debts which the deceased owed him." Finally, article 52 provides: "If anyone has been disseised or deprived by us without lawful judgement of his peers of lands, castles, liberties or his rights we will restore them to him at once; and if any disagreement arises on this, then let it be settled by the judgement of the Twenty-Five barons referred to below in the security clause." See the English translation of the text in Appendix 6 of I.C. Holt, Magna Carta (Cambridge: Cambridge University Press, 1992), 449, at 453, $459 \& 465$.

${ }^{\prime}$ See, generally, K.H.F. Dyson, The State Tradition in Western Europe $\cdots$ A Study of an Idea and Institution (Oxford: Martin Robertson, 1980), at 36-44.

${ }^{52}$ See G. Zeller, L'histoire des relations internationales, vol. 2, Les temps modernes - De Christophe Colomb à Cromwell (Paris: Hachette, 1953), at 18-19.

${ }^{53}$ See J.R. Strayer, supra, note 17, at 48-56.

${ }^{54}$ See, generally, K. Zweigert \& H. Kötz, supra, note 48, at 75-80.

${ }^{35}$ That is, country of written law.

${ }^{56}$ That is, country of customary law. 
and other subordinates being ruined and weakened, the people thus turned to the monarch for protection and guidance. ${ }^{57}$

Even in German areas, in spite of the overlordship enjoyed by the Emperor, the seed of monarchical organisation was planted much before the Peace of Westphalia. ${ }^{58}$ With respect to secular matters, increasingly substantial political concessions were gradually granted in favour of the principalities. ${ }^{59}$ As regards religious matters, several powerful German Princes took the Protestant side in the emerging conflicts and they revolted against the Holy Roman Empire. ${ }^{60}$ These turmoils were settled with the Peace of Augsburg in 1555, ${ }^{\prime \prime}$ between the Emperor and the Protestant Princes, which consecrated the rule of cuius regio eius religio. ${ }^{62}$ Augsburg largely contributed to direct the focus towards the separate polities within the Empire. ${ }^{63}$

This temporary truce in the European religious chaos and the peaceful coexistence it brought deteriorated over the next fifty years. ${ }^{64}$ Especially during the reign of Emperor Rudolf II (1576-1612), restrictions were progressively imposed on the rights to worship freely. ${ }^{65}$ In fact, after the troubles in Donauwörth, ${ }^{66}$ the Treaty of Augsburg was invoked

${ }^{57}$ See P. Daillier \& A. Pellet, supra, note 1, at 48-49.

${ }^{58}$ See, generally, F. Hertz, The Development of the German Public Mind - A Social History of German Political Sentiments Aspirations and Ideas, 2 vols. (London: Allen \& Unwin, 1957 \& 1962).

${ }^{59}$ See infra, at notes 139-144 and accompanying text.

${ }^{60}$ See H. Steinberger, supra, note 35, at 399; and, T.A. Walker, supra, note 18, at 143, who wrote: "The German princely supporters of the Reformed doctrines united in the League of Schmal-kalden (1531), but hesitated and wavered, and at length the Imperial victory of Mühlberg (1547) seemed to ring the death-knell of their hopes. Then, however, Maurice of Saxony, cool-headed and scheming, threw of the mask, and the flight of the Emperor through the Innsbruck pass with the subsequent Treaty of Passau (1552) proclaimed the forceful revival of the Lutberan cause."

6) The Peace of Augsburg recognised and legitimised the Protestant religions (Lutheran and Calvinits) and gave to the ruler the right to determine the religion of its subjects. See J.G. Gagliardo, Germany under the Old Regime, 1600-1790 (London: Longman, 1991), at $16 \mathrm{ff}$; and, R. Jackson, supra, note 7 , at 440.

62 That is, the religion of the king is the religion of the kingdom.

${ }^{63}$ See A.B. Murphy, "The Sovereign State System as Political-Territorial Ideal - Historical and Contemporary Considerations," in T.J. Biersteker \& C. Weber (eds.), State Sovereignty as Social Construct (Cambridge: Cambridge University Press, 1996), 81, at 86. See also C.V. Wedgwood, The Thirty Years War (London: Cape, 1944), at 42, who wrote: "This extraordinary compromise [Augsburg] saved the theory of religious unity for each state while destroying it for the Empire."

${ }^{64}$ See, generally, D. Maland, Europe at War-1600-1650 (London: Macmillan, 1980), at 12-18.

${ }^{65}$ See J.G. Gagliardo, supra, note 61, at 21-23.

tr Pursuant to the Peace of Augsburg, Donauwörth was designated a "parity" city, but later became overwhelmingly Protestant. Feuds between Lutheran burghers and Catholic monks in 1606-1607 degenerated into street brawls which prompted Emperor Rudolf II to put the city under an Imperial ban in order to defend the religious rights of the Catholic minority. 
as the basis for the resurgence of Catholicism. By the beginning of the 17 th century, both camps had their coalitions of armed force: ${ }^{67}$ the Evangelical Union (1608), a Protestant defensive alliance, ${ }^{68}$ and, the Catholic League (1609), a similar organisation for Catholics. ${ }^{69}$ Although the majority of Princes were not in favour of war, some were willing to take advantage of any opportunity to increase their land base and political power.

The rivalries of the time, however, did not stop at the German borders. ${ }^{70}$ England and the United Provinces of the Netherlands allied with the Evangelical Union and were ready to support its cause; in the North, both Denmark and Sweden had ambitions to control the strategic Baltic region; Catholic Spain was preparing to reconquer the Protestant Netherlands; and, France was opposed to the hegemonic aspirations of the Emperor/Spanish King coalition. ${ }^{71}$ This large number of increasingly powerful actors in Europe, in addition to the multilayered system of political authorities, as well as the religious dimension of the different polities, made the violent solution of the situation virtually inevitable.

The spark that ignited the fire came from Bohemia in 1618 with the so-called Defenestration of Prague, ${ }^{72}$ which turned into a revolt against the Emperor and the Catholic domination. The series of wars that followed are known as the Thirty Years War, ${ }^{73}$ which is said to have been the most destructive armed conflict in Europe until the 20 th century. ${ }^{74}$ Originally, the War was primary based on profound religious

\footnotetext{
${ }^{67}$ See G.J. Gagliardo, supra, note 61, at 23-24.

${ }^{68}$ It included at first Palatinate, Württemberg, Neuburg, Baden, Ansbach, Anhalt and some Imperial Cities; it was later expended to include Brandenburg, Hesse-Kassel and other Cities.

${ }^{69}$ It included Bavaria, various bishoprics of Bavaria, Swabia and Franconia, as well as some ecclesiastical polities.
}

${ }^{70}$ See E.A. Beller, "The Thirty Years War," in J.P. Cooper (ed.), The New Cambridge Modern History, vol. 4, The Decline of Spain and the Thirty Years War - 1609-48/59 (Cambridge: Cambridge University Press, 1970), 306, at 306 ff.

${ }^{71} \mathrm{Id}$., at 306 . For a concise account of the political and military situations in Western Europe at the end of the 16 th and the beginning of the 17 th century - including events such as the Union of Utrecht, the defeat of the Invincible Armada and the Massacre of St. Bartholomew, and figures like Elizabeth I and Cardinal Richelieu-see T.A. Walker, supra, note 18, at 144-147.

${ }^{22}$ On 23 May 1618, a group of Protestants in Prague invaded the Imperial palace and threw two Catholic members of the Bohemian Council out a window, some 70 feet above the ground. The rarely told aspect of the story, however, is that the officials fell into a pile of manure and suffered only minor injuries!

${ }^{73}$ See, generally, H. Sacchi, La Guerre de trente ans, 3 vols. (Paris: Harmattan, 1991); G. Parker, The Thirty Years' War (London: Routledge \& Kegan Paul, 1984); J.V. Polisensky, The Thirty Years War (London: Batsford, 1971); T.K. Rabb (ed.), The Thirty Years' War ... Problems of Motive, Extent and Effect (Boston: Heath, 1964); and, G. Pagès, La guerre de trente ans - 16181648 (Paris: Payot, 1949).

${ }^{74}$ According to J. Perré, La guerre et ses mutations - Des origines à 1792 (Paris: Payot, 1961), 
antagonism, but these motives only lasted for the first decade of the conflicts. The power politics of the belligerents, which was never absent, came to finally predominate the main battles, which were fought on German soil between France and Sweden, on the one side, and the Habsburgs and their allies, on the other. ${ }^{75}$ The negotiations to end the War took place from 1644 to $1648^{76}$ and culminated in the Peace of Westphalia, without any decisive victory by anyone. ${ }^{77}$

At this stage of the discussion, the most important point to acknowledge is that, by the 17 th century, Europe was no longer dominated by the Holy Roman Empire or the Papacy. ${ }^{78}$ The supreme authority over spiritual and temporal spheres was not exclusively lying anymore - assuming that it once was- in the hands of transcendental institutions. Instead, distinct separate polities both within and without the Empire had started to

at 409 , the German population declined from 21 to 13 million because of the Thinty Years War. See also G. Franz, Der Dreissigjährige Krieg und das deutsche Volk, 3rd ed. (Stuttgart, Germany: Gustav Fischer Verlag, 1961), at 47, who estimated that $40 \%$ of the rural and 33\% of the urban population of Germany perished as a result of the War and its aftermath, such as the plague.

${ }^{75}$ On the motives behind the conflicts that shifted from religion to politics, see T.A. Walker, supra, note 18, at 157, who noted: "Christendom mobilised under opposing flags, and the barriers between people and people and the ties of national allegiance were in the first instance forgotten in the fervour of religious opinion. When, however, the course of the struggle made it evident that the two great hostile armies must be finally content to partition the field of battle, and a clear rule of distribution was looked for, Nationality stepped from behind Religion and asserted effectual the claims."

The Thirty Years War conflicts are usually divided by historians into four phases, customarily styled and dated as follows: the Palatine-Bohemian period (1618-1623), ended by the Battle of White Mountain with a Catholic victory; the Danish period (1624-1629), another Catholic triumph consecrated by the Treaty of Lübeck; the Swedish period (1630-1635), which saw the Treaty of Prague officialise an indecisive Catholic victory; and, finally, the French period (1635-1648), which lead to the Peace of Westphalia. See, generally, E.A. Beller, supra, note 70, at $307 \mathrm{ff}$.

${ }^{76}$ On the negotiations that led to the settlement of the Thirty Years War, from original sources, see G. - H. Bougeant, Histoire du Traité de Westphalie, ou des Negociations qui se firent à Munfter \& à Ofnabrug, 6 vols. (Paris: n.b., 1751); and, J. Le Clerc, Negociations Secretes touchant la Paix de Munfter et d'Osnabrug, 4 vols. (The Hague: Neaulme, 1725 \& 1726).

${ }^{77}$ See K.J. Holsti, supra, note 4, at 29, who wrote: "The war came to an end not because of any great commitment to peace in the abstract or because of decisive military victories and defeats. Rather, the parties exhausted themselves."

It is noteworthy, however, that 1648 did not mark the end of armed conflicts in Europe. The war between France and Spain continued until the Peace of the Pyrenees in 1659. As well, the war between Sweden and Poland, and that between Sweden and Denmark, only ended in 1660 with the Peace of Olivia and the Peace of Copenhagen. See $i d$, at 41.

${ }^{78}$ See G.R.R. Treasure, The Making of Modern Europe, 1648-1780 (London \& New York: Methuen, 1985), at 374; J. Bryce, Studies in History and Jurisprudence, vol. 2 (Oxford: Clarendon Press, 1901), at 82 ff: E.N. van Kleffens, supra, note 22, at 38-39; and, I.A. Camilleri, supra, note 14 , at 14 . 
establish a solid foundation based on the idea of political autonomy. Indeed, what is considered a nowveau régime did not come into existence by enchantment through the stroke of a pen at bottom of some peace documents. ${ }^{79}$ Rather, in the words of T.A. Walker:

"The new Order arose by the positive and negative establishment of the authority of Feudal Monarchy; by the victory of that Monarchy in the struggle with baronial disorder, and by the defeat alike of Papacy and of Holy Roman Empire in the attempt to establish an effective World Sovereignty." 80

The so-called constitutio Westphalica ${ }^{81}$ will now be examined to demonstrate that the general view that it can legitimately be credited for the birth of our state system is a mere international legal reification. ${ }^{82}$

\section{The Peace Treaties and their Ramifications}

The Peace of Westphalia, formalised on 24 October 1648, was in fact composed of two separate agreements. The Treaty of Osnabrück was concluded between two groups of political entities: on the one hand, the Protestant Queen of Sweden and her allies and, on the other, the Holy Roman Habsburg Emperor and the German Princes. The Treaty of Münster was also concluded between two groups: one the one hand, the Catholic King of France and his allies and, on the other, the Emperor and the Princes. ${ }^{83}$ These

\footnotetext{
${ }^{79}$ See G. Sørensen, "Sovereignty: Change and Continuity in a Fundamental Institution" (1999), 46 Political St. 590, at 591, who expressed the following view concerning the Peace of Westphatia: "The world did not change overnight at a specific point in time; elements of the old system remained in place for a long period. There was no momentous change from one day to the next in 1648."

${ }^{80}$ T.A. Walker, supra, note 18 , at 84 . See also J. Bryce, supra, note 26 , at 340 , who once noted that Westphalia "did no more than legalize a condition of things already in existence."

${ }^{81}$ That is, the Westphalian constitution. See also P. Daillier \& A. Pellet, supra, note 1, at 50, who spoke of the "Charte constitutionnelle de l'Europe."

82 See A. Carty, "Critical International Law: Recent Trends in the Theory of International Law" (1991), 2 European J. Int'l L. 66, at 67, footnote 1, who defined reification as meaning, "to consider or to make an abstract idea or concept real or concrete." He also gave an example taken from his book The Decay of International Law? * A Reappraisal of the Limits of Legal Imagination in International Affairs (Manchester: Manchester University Press, 1986), showing that international jurists put into legal language variants of liberal political theory and then treated them as accepted by the international community.

${ }^{83}$ For the full text of the Osnabrïck and Münster Treaties, in both their Latin and English versions, see C. Parry (ed.), Consolidated Treaty Series, vol. 1 (Dobbs Ferry, U.S.: Oceana Publications, 1969), at 119 \& 270. [hereinafter Treaty Series] It is the English translation that will be used, which Parry said is taken from the General Collection of Treatys; the old English spelling modernised and everywhere else language modernised.
} 
agreements were thus bilateral in nature, which reffects the practice of the time that had not yet evolved to the making of multilateral treaties. ${ }^{84}$

Although the Treaties paid homage to the unity of Christendom, ${ }^{85}$ it is significant that they involved several polities. ${ }^{86}$ Sweden and France insisted on having the German Princes as parties to the Peace, a strategy meant to weaken the position of the Emperor. As a consequence, the Treaties became instruments not only to bring peace between the former belligerents, but also to deal with constitutional matters within the Empire. ${ }^{87}$ Article 70 of the Münster Treaty declared:

"For the greater Firmness of all and every one of these Articles, this present Transaction shall serve for a perpetual Law and established Sanction of the Empire, to be inserted like other fundamental Laws and Constitutions of the Empire in the Acts of the next Diet of the Empire, and the Imperial Capitulation; binding no less the absent than the present, the Ecclesiastics than Seculars, whether they be the States of the Empire or not: insomuch as that it shall be a prescribed Rule, perpetually to be followed, as well by the Imperial Counsellors and Officers, as those of other Lords, and all Judges and Officers of Courts of Justice." 88

\footnotetext{
${ }^{84}$ See T. Meron, "The Authority to Make Treaties in the Late Middle Ages" (1995), 89 American J. Int'l L. 1, at 6-7. See also, generally, C.W. Jenks, "Les instruments internationaux à caractère collectif" (1930), 69 R.C.A.D.I. 448; and, A.D. McNair, Law of Treaties $\cdots$ British Practice and Opinions (Oxford: Clarendon Press, 1938), at 4-6.

${ }^{85}$ Towards the end of the Osnabrück Treaty's preamble, it stated that the parties "agreed among themselves, to the Glory of God, and Safety of the Christian World;" similarly, in the Münster Treaty, one can read that the agreement was reached "to the Glory of God, and the Benefit of the Christian World;" [spelling modernised] see Treaty Series, at 199-200 \& 321. See also A. Osiander, The States System of Europe, 1640-1990-Peacemaking and the Conditions of International Stability (Oxford: Clarendon Press, 1994), at 27-30, who noted that the rulers' representatives at the Peace conferences viewed themselves as part of a community based on the Christian religion.

Westphalia and the Peace of Utrecht in 1713 were among the last treaties to still refer to the Christendom; see R. Jackson, supra, note 7, at 439.

${ }^{86}$ The preamble of the Osnabrïck Treaty, in fine, stated: "[T]he Electors, Princes and States of the Sacred Roman Empire being present, approving and consenting;" likewise, the Münster Treaty's preamble ended: [1]n the presence and with the consent of the Electors of the Sacred Roman Empire, the other Princes and States;" see Treaty Series, at 200 \& 321. [emphasis in original] [spelling modernised] As well, there are mentions of the different polities making up the Empire - some 332 of them - throughout the two treaties of Westphalia; see A.D. McNair, supra, note 1 , at 70 .

${ }^{87}$ See R. Lesaffer, "The Westphalia Peace Treaties and the Development of the Tradition of Great European Peace Settlements Prior to 1648" (1997), 18 Grotiana 71, at 71 \& 77.

$\$ 8$ Treaty Series, at 353. [spelling modernised]
} 
These numerous actors from both within and without the Empire ${ }^{89}$ seem to bear witness to the termination of the Imperial transcendental domination in Europe. The following analysis, however, will go beyond this facade and will challenge the view that Westphalia consecrated the idea of autonomous distinct separate polities.

First and foremost, building on the acquis from the Peace of Augsburg in 1555, ${ }^{90}$ the main object of the Peace of Westphalia was to establish a regime on religious practice and denominational matters. ${ }^{9 !}$ Although the Treaties did not explicitly abandon the principle that the monarch could determine the religion of the land, they nevertheless provided for important constitutional safeguards. Indeed, several provisions were inserted to circumscribe and restrain the Princes' formerly absolute authority over the religious sphere. ${ }^{92}$ The most material one, at Article 5, paragraph 11 , established that a ruler who chose to change its religion could not compel its subjects to do the same..$^{93}$

The Treaties formally recognised freedom of conscience for Catholics living in Protestant areas and vice versa, which included the rights to worship and to religious education. Article 5, paragraph 28, of the Treaty of Osnabrück thus read:

"It has moreover been found good, that those of the Confession of Augsburg [i.e. Protestants], who are Subjects of the Catholics, and the Catholic Subjects of the States of the Confession of Augsburg, who had not the public or private Exercise of their Religion in any time of the year 1624. and who after the Publication of the Peace shall profess and embrace a Religion different from that of the Lord of the Territory, shall in consequence of the said Peace be patiently suffered and tolerated, without any Hindrance or Impediment to attend their Devotions in their Houses and in Private, with all Liberty of Conscience, and without any Inquisition or Trouble, and even to assist in their Neighbourhood, as often as they have a mind, at the public Exercise of their Religion, or send their children to foreign Schools of their Religion, or have them instructed in their Families by private Masters; provided the said Vassals

${ }^{89}$ K.I. Holsti, supra, note 4 , at 25 wrote: "The congresses [of Westphalia] brought together the main heterogeneous political units of Europe at that time. There were 145 delegates representing 55 jurisdictions, including the Holy Roman Empire and all the major kingdoms except Great Britain [and Russia], as well as significant duchies, margraves, landgraves, bishoprics, free cities, and imperial cities." [citation omitted]

See also, generally, A.W. Ward, "The Peace of Westphalia," in A.W. Ward, G.W. Prothero \& S. Leathes (eds.), The Cambridge Modern History, vol. 4, The Thirty Wars' War (Cambridge: Cambridge University Press, 1934), 395.

${ }^{90}$ See supra, at notes 60-63 and accompanying text.

${ }^{91}$ See G. Pagès, supra, note 73, at 247-249. See also, on the religious practices before and after Westphalia, S.D. Krasner, "Sovereignty and Intervention," in G.M. Lyons \& M. Mastanduno (eds.), Beyond Westphalia? ... State Sovereignty and International Intervention (Baltimore, U.S. \& London: Johns Hopkins University Press, 1995), 228, at 234-236.

${ }^{92}$ See A.W. Ward, supra, note 89 , at 416.

"3. Treaty Series, at 218-219. 
and Subjects do their Duty in all other things, and hold themselves in due Obedience and Subjection, without giving occasion to any Disturbance or Commotion." 94

As well, such dissenters were not to be "excluded from the Community of Merchants, Artisans or Companies, nor deprived of Successions, Legacies, Hospitals, Lazar-Houses, or Alms-Houses, and other Privileges or Rights." People living in denominationally mixed cities - Augsburg, Dunckelfpiel, Biberach, Ravensburg, Kauffbeur - were free to practice their religion without any "molest or trouble." $\%$

Osnabrück also promoted equality between Catholics and Protestants in the assemblies of the Diet and in other decision-making institutions of the Empire. ${ }^{97}$ For example, article 5, paragraph 42, stated: "In the ordinary Assemblies of the Deputies of the Empire, the Number of the Chiefs of the one and the other Religion shall be

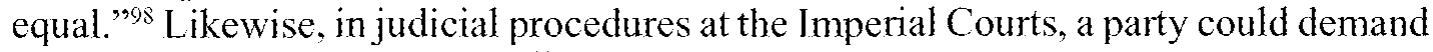
the religious parity of judges. ${ }^{99}$ These rights afforded to the Lutheran Protestants ("Confession of Augsburg") were extended to Calvinist Protestants (the "Reformed"). ${ }^{100}$

The second main object of the Peace of Westphalia concerned territorial settlements, which turned on the satisfaction of Sweden and France. Sweden's traditional claims with respect to the south shore of the Baltic region were given effect in the Treaty of Osnabrück. Accordingly, Western Pomerania, the islands of Rügen, Usedom and Wollin, the bishoprics of Bremen and Verdun, and the port of Wismar passed under the Swedish Crown ${ }^{101}$. It must be emphasised, however, that the conveyances were not total: Sweden was to hold these territories as Imperial fiefs. ${ }^{i 12}$ Indeed, article 10 of the Osnabrück Treaty repetitively stated that all transfers were "in perpetual and immediate Fief of the Empire." ${ }^{03}$ As a result, the Swedish ruler was to occupy seats in the Diet to represent these regions within the Empire.

Pursuant to the Treaty of Münster, France was granted territories "with all manner of Jurisdiction and Sovereignty, without any contradiction from the Emperor, the Empire, House of Austria, or any other." 104 Unlike Sweden, therefore, the French Crown received full title in, and authority over, most of the territories transferred, ${ }^{105}$ which included the

\footnotetext{
${ }^{94}$ See Treaty Series, at 228-229. [emphasis in original] [spelling modernised]

"Article 5, paragraph 28, id., at 229. [spelling modernised]

${ }^{96}$ Article 5, paragraph 24, id., at 225-227. [spelling modernised]

${ }^{97}$ See A.W. Ward, supra, note 89, at 414.

98 Treaty Series, at 234-235. [spelling modernised]

(9) Article 5, paragraph 45, id., at 237-238.

${ }^{300}$ See article 7, id., at 239-240. [emphasis in original] [spelling modernised]

${ }^{301}$ See article 10, id., at $244-249$.

102 See A.W. Ward, supra, note 89, at 403-404.

${ }^{103}$ Treaty Series, at 244-247.

${ }^{104}$ Article 76, id., at 341. [emphasis in original] [spelling modernised]

105 See A.W. Ward, supra, note 89, at 404-405.
} 
bisoprics of Metz, Toul and Verdun, ${ }^{106}$ as well as the area known as Pinerolo. ${ }^{107}$ The rights of the House of Austria in the region of Alsace were also conveyed to France, ${ }^{108}$ but not without a substantial qualification. Indeed, article 92 provided:

"That the most Christian King shall be bound to leave not only the Bishops of Strasbourg and Bafle, with the City of Strasbourg, but also the other States or Orders, Abbots of Murbach and Luederen, who are in the one and the other Alsatia, immediately depending upon the Roman Empire; the abbess of Andlavien, the Monastery of St. Bennet in the Valley of St. George, the Palatines of Luzelftain, and all the nobility of Lower Alsatia; Item, the said ten Imperial Cities, which depend on the Mayory of Haganoc, in the Liberty and Possession they have enjoyed hitherto, to arise as immediately dependent upon the Roman Empire; so that he cannot pretend any Royal Superiority over them, but shall rest contended with the Rights which appertained to the House of Austria, and which by this present Treaty of Pacification, are yielded to the Crown of France. In such a manner, nevertheless, that by the present Declaration, nothing is intended that shall derogate from the Sovereign Dominion already bereabove agreed to."109

Consequently, although they formally passed under the French Crown, these parts of the Alsatian territory nevertheless maintained some sui generis autonomist status based on Imperial privileges. ${ }^{100}$

The Treaty provisions relating to religious practice and denominational matters, as well as those pertaining to the territorial satisfaction of Sweden and France, undoubtedly represent the two main objects of the Peace of Westphalia. ${ }^{11}$ The parties also formally recognised the United Provinces of the Netherlands ${ }^{112}$ and explicitly provided for the independence of the Swiss Confederation, ${ }^{113}$ which were already at this point faits

\footnotetext{
${ }^{106}$ See article 71, Treaty Series, at 340.

${ }^{107}$ See article 73 , ibid.

${ }^{308}$ See article 74, id., at 340-341.

${ }^{169} \mathrm{Id}$., at 345 . [emphasis in original] [spelling modernised]

176) See G. Pagès, supra, note 73, at 258-259.

${ }^{113}$ See K.J. Holsti, supra, note 4, at 34.

${ }^{112}$ At the conclusion of the conflict between the United Provinces and Spain, the latter recognised the territorial boundaries of the Netherlands in a peace treaty signed on 30 January 1648, also at Münster. As a consequence, these territories were excluded from the Burgundian Imperial Circle during the negotiations at Westphalia which, implicitly, legally ratified the Dutch independence from the Holy Roman Empire. See J.V. Polisensky, supra, note 73, at 236-237; and, G. Pagès, supra, note 73 , at 254 .

${ }^{113}$ Switzerland's independence was legally consecrated in article 63 of the Treaty of Münster, which stated: "And as His Imperial Majesty, upon Complaints made in the name of the City of Bafle, and of all Switzerland, in the presence of their Plenipotentiaries deputed to the present Assembly, touching some Procedures and Executions proceeding from the Imperial Chamber against the said City, and the other united Cantons of the Swiss country, and their Citizens and
} 
accomplis. ${ }^{34}$

According to the school of thought that considers 1648 as a break from the ancien régime, there is another highly material provision in the agreements which would epitomise statehood, namely that dealing with the delegation of power to conclude treaties. ${ }^{15}$ At article 65, the Treaty of Münster read:

"They [the German polities] shall enjoy without contradiction, the Right of Suffrage in all Deliberations touching the Affairs of the Empire; but above all, when the Business in hand shall be the making or interpreting of Laws, the declaring of Wars, imposing of Taxes, levying or quartering of Soldiers, erecting new Fortifications in the Territories of the States, or reinforcing the old Garisons; as also when a Peace or alliance is to be concluded, and treated about, or the like, none of these, or the like things shall be acted for the future, without the Suffrage and Consent of the Free Assembly of all the States of the Empire: Above all, it shall be free perpetually to each of the States of the Empire, to make Alliances with Strangers for their Preservation and Safety; provided, nevertheless, such Alliances be not against the Emperor, and the Empire, nor against the Public Peace, and this Treaty, and without prejudice to the Oath by which every one is bound to the Emperor and the Empire."116

Article 8, paragraph 1 , of the Osnabrück Treaty was to the same effect. ${ }^{17}$ Therefore, the political entities making up the Empire were given the power to independently make agreements between themselves and with other countries. This competence, however, was explicitly limited by the caveat according to which no such alliance could be directed against the imperium or be in breach of the Peace of Westphalia itself. ${ }^{118}$ Also significant is that, except for treaty-making, these provisions confirmed

Subjects having demanded the Advice of the States of the Empire and their Council; these have, by a Decree of the 14th of May of the last Year, declared the said City of Bafle, and the other Swiss-Cantons, to be as it were in possession of their full Liberty and Exemption of the Empire; so that they are no ways subject to the Judicatures, or judgments of the Empire, and it was thought convenient to insert the same in this Treaty of Peace, and Confirm it, and thereby to make void and annul all such Procedures and Arrests given on this Account in what form soever;" see Treaty Series, at 337. [emphasis in original] [spelling modernised]

${ }^{34}$ See G. Pagès, supra, note 73 , at 254, who wrote as regards the Netherlands and Switzerland: "Enfin divers articles légalisent un état de fait déjà ancien, mais qui n'avait pas encore la garantie d'un instrument diplomatique." [emphasis added] See also F. Hertz, The Development of the German Public Mind - A Social History of German Political Sentiments Aspirations and Ideas, vol. 2, The Middle Ages - The Reformation (London: Allen \& Unwin, 1962), at 515; E.A. Beller, supra, note 70, at 358; and, T.A. Walker, supra, note 18, at 148.

${ }^{115}$ See K.I. Holsti, supra, note 4, at 35-36.

[16 Treaty Series, at 337-338. [emphasis added] [spelling modernised]

${ }^{117}$ Id., at 241. See also, R. Lesaffer, supra, note 87, at 71 .

"18 The legislative history of these provisions shows that the parties originally meant to go much further than what was provided for in the final version of the Münster Treaty. The proposition 
to the Imperial Diet all other powers usually linked with the exercise of supreme authority - legislation, warfare and taxation.

Moreover, it appears that these Treaty articles merely recognised a practice which had already been in existence for almost half a century. Indeed, the powerful German Princes were conducting their own foreign policy long before Westphalia. Palatinate and Brandenburg, for instance, struck alliances with the United Provinces of the Netherlands in 1604 and 1605 respectively. ${ }^{319}$ Further, most rulers within the Empire formed part of the armed force coalitions - the Evangelical Union and the Catholic League - that existed at the outbreak of the Thirty Years War. ${ }^{120}$ In light of this, it becomes more difficult to contend that the articles concerning the treaty-making power are groundbreaking and constitute hard evidence of a new independent status for distinct separate polities.

The rest of the provisions in the two documents finalised in 1648 related to rather secondary issues. ${ }^{121}$ They included matters such as a general amnesty going back to the Bohemian troubles, the neutralisation of certain territories, the restitution of property and the renouncement of debts, the re-establishment of commerce and trade, the hereditary succession in some German monarchies, as well as the general representation in Imperial institutions and the election of the Emperor.

In summary, the principal objects and material provisions of the Osnabrück and Münster Treaties do not by and large support the traditional position that the Peace of Westphalia constitutes a paradigm shift whereby the political entities involved gained exclusive power over their territories. The two main purposes of the agreements related to the practice of religion and the settlement of territories, not to the creation of distinct separate polities independent from any higher authority. As regards religious matters, the German Princes did not even retain their existing power; au contraire, the rule of cuius regio eius religio was circumscribed by denominational protections for minorities and equality guarantees were provided for Catholics and Protestants.

Furthermore, the Empire remained a key factor according to Westphalia. Indeed, it is through Imperial institutions - such as the Diet and the Courts - that religious

made by the French on 11 Jane 1645 was unqualified and even used the language of sovereignty. Indeed, article 8 of the said proposition read: "Que tous lesdits Princes \& Etats en général \& en particulier seront maintenus dans tous les autres droits de Souveraineté qui leur appartiennent, \& spécialement dans celui de faire des confédérations tant entre eux qu'avec les Princes voisins, pour leur conservation \& sureté;" [emphasis added] [spelling modernised] see G.-H. Bougeant, Histoire du Traité de Westphalie, ou des Negociations qui se firent à Munfter \& à Ofnabrug, vol. 3 (Paris: n.b., 1751), at 428-429. Therefore, it can be argued that the compromised article 65 in the Treaty of Münster constituted a victory on the part of the Holy Roman Empire.

${ }^{119}$ See G. Parker, supra, note 73, at 2, who noted that, along with England and France, Palatinate and Brandenburg struck treaties of friendship with the Netherlands, which help the latter's effort against Spain.

${ }^{320}$ See supra, at notes 68-69 and accompanying text.

${ }^{121}$ See, generally, H. Sacchi, La Guerre de trente ans, vol. 3, La Guerre des cardinaux (Paris: Harmattan, 1991), at 477-484; and, K.J. Holsti, supra, note 4, at 36. 
safeguards were imposed in decision-making process. With respect to territorial settlements, the satisfaction of Sweden was given in terms of fiefdoms within the Empire, thus acknowledging an enduring overlordship for the Emperor. Vis-à-vis France, although no Imperial feudal link remained after most of the land transfers, some parts of Alsace maintained their autonomist status granted by the House of Austria. Finally, it was just shown that the power to conclude alliances formally recognised to the German Princes was not unqualified and, in effect, had been exercised long before 1648 .

In fact, what Westphalia marks is nothing more than another step towards the progressive shift from the ideal of a universal overlordship to the concept of distinct separate political entities enjoying a larger degree of independence. ${ }^{122}$ Indeed, the confinement of the transcendental institutions and the erosion of their authority over both spiritual and temporal spheres did not start, and certainly did not end either, with the Peace.

In the final part of the analysis, the post 1648 period in Germany must be considered in order to assess the situation of the Holy Roman Empire following Westphalia.

\section{The Empire and Westphalia's Aftermath}

Even if the Treaties of Osnabrück and Münster did not create, de jure, a system of independent states, perhaps they nevertheless constitute a turning point after which, de facto, the imperium's atrophy allowed the German distinct separate polities to effectively exercise exclusive control and power over their territories. The last part of the paper will show that it was not the case and that Europe's last transcendental entity, i.e. the Holy Roman Empire, did not disappear as an aftermath of the Peace of Westphalia. ${ }^{123}$

In the 17 th and 18 th centuries, the principal German political entities within the

\footnotetext{
${ }^{122}$ See T.A. Walker, supra, note 18 , at 148, who, speaking of the hybrid political status of the Empire and its constituting parts in 1648 , noted: "The territorial state had long existed in point of fact, but, whilst each royal, ducal, or republican ruler of provinces had failed to tecognise in his frontiers the precise limits of his jurisdiction, the sense of national independence had been held down in pupilage (sic) by the awe-inspiring shadow of a majestic common superior." See also M. Wight, supra, note 36 , at 152 , who wrote: "At Westphalia the states-system does not come into existence: it comes of age."

${ }^{223}$ One may recall that Voltaire notoriously quipped that the German Empire was "neither Holy, nor Roman, nor an Empire;" see L.C. Buchheit, Secession - The Legitimacy of Self-Determination (New Haven \& London: Yale University Press, 1978), at 8. Pufendorf's view of the Empire was that of "an irregular state-body, much like a monster;" see J.G. Gagliardo, Reich and Nation ... The Holy Roman Empire as Idea and Reality, 1763-1806 (Bloomington, U.S.: University of Indiana Press, 1980), at 41; it must be stressed, however, that the terms "monstrosity" (in Latin monstrum) and "irregularity" were almost synonyms in the writings of the 17 th and 18 th century - see infra, note 158.

These quotes from philosophers bear witness to how important, yet immensely difficult, it has been to describe and ascertain the nature of the Holy Roman Empire of the German Nation. The objective of this brief review of the Imperial institutions is much more modest: to show that the Empire, whatever it was, did not end following Westphalia.
} 
Empire could be gathered in the following categories: Ecclesiastical Principalities (dominated by Catholic Princes), Secular Principalities (dominated by Protestant Princes), Imperial Cities, and families of Imperial Counts and Knights. ${ }^{124}$ Some of the Secular Principalities - Brandenburg/Prussia, Electoral Saxony, Bavaria, the Palatinate, Hesse, Trier, and Württemberg - were antagonistic to the Imperial authority and challenged the prerogatives of the Emperor. The other Secular Principalities, as well as Ecclesiastical Principalities, Imperial Cities, Counts and Knights, supported the Empire and were in favour of its institutions. ${ }^{125}$

These bodies included the Diet and the Emperor himself, as well as the Imperial Courts, the Imperial Circles and the Imperial Army. ${ }^{126}$ The Diet's main functions were advisory and legislative; it also constituted the adjudicator of final appeal. ${ }^{127}$ Laws duly enacted by the Diet and sanctioned by the Emperor bound the Empire in its entirety, ${ }^{128}$ hence the adage Rechsrecht bricht Landerecht. ${ }^{129}$ Accordingly, it was originally intended to be the most important Imperial institution after the Emperor. The Treaty of Osnabrück modified the composition of the Diet through denominational equality guarantees. ${ }^{13 t)}$ Furthermore, article 5, paragraph 43 , of this Treaty provided:

"In matters of Religion, and in all other Affairs, wherein the States cannot be considered as one Body, and when the Catholic States and those of the Confession of Augsburg are divided into two Parties; the Difference shall be decided in an amicable way only, without any side's being tied down by a Plurality of Voices. However, as to what concerns the Plurality of Voices in the matter of Impositions, that Affair not being capable of being decided in the present Assembly, it shall be remitted to the next Diet." "\$1

\footnotetext{
${ }^{124}$ See J.G. Gagliardo, id., at 3-15. As regards the Imperial Constitution, the series of legal agreements forming it throughout the existence of the Empire include the Golden Bull in 1356, the Eternal Peace in 1495, the Treaty of Passau in 1552, the Peace of Augsburg in 1555, the Peace of Westphalia in 1648, the Electoral Capitulations since 1519, the Peace of Teschen in 1779, and the Final Recess of the Imperial Deputation in 1803.

125 See S.D. Krasner, supra, note 7, at 247-248.

126 See J.G. Gagliardo, supra, note 123, at 16-46, who underscored that these institutions "functioned essentially unchanged for a century and a half following the Peace of Westphalia;" see, id., at 16 .

${ }^{127}$ The Treaty of Osnabrück, at article 8, assigned to the Diet an almost indefinite programme of work; see Treaty Series, at 241-243. See also G. Pagès, supra, note 73, at 246.

${ }^{328}$ The Diet was formed of three councils: the Council of Electors, the Council of Princes, and the Council of Cities. A majority vote in two of the three bodies was needed to submit a proposal to the Emperor, on which he had the final say.

${ }^{29}$ That is, Imperial law breaks territorial law.

${ }^{130}$ See supra, at notes 97-100 and accompanying text.

${ }_{131}$ Treaty Series, at 235. [emphasis in original] [spelling modernised]
} 
It was thus necessary that religious issues be approved by both the corpus Evangelicorum $^{332}$ and the corpus Catholicorum. ${ }^{133}$ This consensus requirement ${ }^{134}$ meant that, after 1648 , it became considerably more difficult for the Diet to fulfil its legislative functions. ${ }^{135}$

Although it remained in permanent session starting in $1663,{ }^{136}$ very little at all was accomplished in the Diet, mainly because of deadlocks caused by denominational equality or lack of unanimity. The consequential impeded leadership and direction given to the Empire as a whole was fertile ground for the subordinate German polities to claim and, indeed, exercise power over their territories. ${ }^{137}$ However, the Diet nevertheless constituted a forum within the Imperial system where issues of national concerns could at least be considered and debated. ${ }^{138}$ One must acknowledge as well that it is only in the middle of the 18 th century - i.e. one-hundred years after the Peace

${ }^{132}$ That is, body of Protestants.

${ }^{133}$ That is, body of Catholics.

${ }^{134}$ This distinction based on denomination existed in addition to the division of the Diet into three councils. It meant that the voting on religious matters was done in a plenary assembly of all representatives, who sided in their respective Catholic and Protestant groups. See J.G. Gagliardo, supra, note 123, at 24.

${ }^{135}$ See P. Schröder, "The Constitution of the Holy Roman Empire after 1648: Samuel Pufendorf"s Assessment in his Monzambano" (1999), 42 Historical J. 961, at 979-980, who wrote: "The Protestants realized immediately that they could exploit the right of separating into two different religious congregations for their own ends. By claiming that most of the disputed matters were matters of religious controversy, and thus enforcing the itio in partes, they were able to assert that the decision reached in the particular Protestant corpus was the only binding agreement for them, and that the Catholies had no right to intervene or challenge these discussions. This tactical manoeuvring impeded the Diet seriously, while the Emperor attempted to stress the unity of the Empire."

${ }^{336}$ Since the Diet was convoked by the Emperor and fearing that the latter could dissegard its constitutional role by not calling sessions, the representatives refused to disband the Diet after 1663. Therefore, it theoretically remained in permanent session until the end of the Empire in 1806 , hence the nickname "Eternal Diet" of Regensburg. See J.G. Gagliardo, supra, note 123, at 21.

157 See H. Sacchi, supra, note 121, at 482, who wrote: "L'unanimité sur les problèmes constitutionnels ou religieux importants étant en réalité impossible à atteindre, cette institution, qui siégea jusqu'au milieu du XIXème siècle, devint le point où s'accumulèrent tous les dossiers essentiels de l'empire, et paralysa en fait toute réforme."

${ }^{138}$ It is through the Diet that the notorious mystical formula Kaiser und Reich emerged to signify both the unity and the division within the Holy Roman Empire. According to J.G. Gagliardo, supra, note 123 , at 2$\}$, this expression was "intended to convey the sense of a kind of coequal responsibility of head and members for the preservation of harmony of a single body, a higher unity within diversity." The English language cannot properly convey the precise adjectival distinction between Kaiser and Reich, which would be translated at best as "Emperor" and "Empire." 
of Westphalia - that the Diet became dysfunctional.

The other Imperial institutions were also somewhat affected by the Treaties of Osnabrück and Münster. However, they continued to play their unremitting roles within the increasingly decentralised Empire for years after the Peace: ${ }^{139}$ the political activities of the Imperial Circles remained instrumental in most areas; the jurisdiction of the Imperial Courts steadily shrunk but lingered until the 18th century; and, the command of the Imperial Army abided with the Emperor and his Reichs-Generalfeldmarschälle. ${ }^{140}$

The last, but not least, of the Imperial institutions was the Emperor himself, whose gradual decline in power owed nothing substantial to Westphalia. ${ }^{141}$ Indeed, it is rather the expansion of the Landeshoheit ${ }^{142}$ principle - imposed on Emperor Charles $V$ in 1519 and enacted into Imperial law in 1711 - which gave German distinct separate political entities ever expanding control and authority over their territories at the expense of the imperium. ${ }^{143}$ Significantly, this progressive erosion of the universal Imperial power began centuries before 1648. ${ }^{144}$ According to the historian John Gagliardo, it can be traced back to the Golden Bull in 1356, which first prescribed the legal modalities for the election of the Emperor. ${ }^{145}$

Since this landmark in the constitutional annals of the Empire, and up to the Reichsdeputationshauptschluss ${ }^{146}$ of 1803 , three years before their demise, the Emperor and the other institutions underwent piecemeal and virtually uninterrupted reduction

${ }^{339}$ For a detailed analysis of the Imperial Circles, the Imperial Courts and the Imperial Army, see J.G. Gagliardo, $i d$., at 26-39.

${ }^{340}$ That is, Imperial General-Field Marshals, who acted as the supreme military representatives of the Emperor.

${ }^{141}$ Contra, or rather somewhat ambiguously, see D. McKay \& H.M. Scott, The Rise of the Great Powers - 1648-1815 (London \& New York: Longman, 1983), at 5, who wrote: "The idea that the Empire itself was an actual state, capable of pursuing its own policies, was finally dead [with Westphalia]. This did not mean, however, that the emperor was now powerless within the Holy Roman Empire or that the Imperial title had no value. Emperors continued after 1648 to interfere within Germany and to have a great deal of influence there, particularly among the smaller states." [emphasis added]

${ }^{142}$ That is, territorial lordship.

${ }^{143}$ See F. Hertz, The Development of the German Public Mind $\cdots$ A Social History of German Political Sentiments Aspirations and Ideas, vol. 1, The Age of Enlightenment (London: Allen \& Unwin, 1957), at 14.

${ }^{144}$ Further, it was shown in a previous part of the paper that the Emperor's authority vis-à-vis other European territories such as Spain, England and France disappeared centuries before. See supra, at notes 39-42 and accompanying text.

145 See J.G. Gagliardo, supra, note 123, at 18-19. See also, generally, H. Gross, "The Holy Roman Empire in Modern Times: Constitutional Reality and Legal Theory," in J.A. Vann \& S.W. Rowan (eds.), The Old Reich: Essays on German Political Institutions, 1495-1806 (Brussels: Librairie Encyclopédique, 1974), 1.

${ }^{146}$ That is, the Final Recess of the Imperial Deputation. 
of function and power. But it is only as a result of Napoleon's conquest of Germany in $1806^{347}$ that the Holy Roman Empire ceased to exist. ${ }^{148}$ As Paul Guggenheim put it:

"Mais il fallut quand même attendre jusqu'à la dissolution de l'Empire, en 1806, pour qu'une modification fondamentale se produise dans la situation juridique; les territoires dont les princes avaient réussi à s'assurer la puissance publique devinrent des États souverains, englobant les seigneuries dont les titulaires n'avaient pas accédé à la même position." "19

Noteworthy also is that the imperium disappeared not because of political struggles within, but because of an external force unrelated to the Empire's transcendentality Napoleonic France, the hegemonic power in Europe then. ${ }^{150}$

It is appropriate to end this last part of the paper with a brief account of the theoretical assessment of the Imperial political organisation given by the intellectuals of the time. Unsurprisingly, they could not agree on who between the Emperor and the Princes held the ultimate authority over the German territory. ${ }^{151}$ Using the Aristotelian categories of polities - monarchy, aristocracy or democracy ${ }^{152}$ - Jean Bodin opined that the Empire was not a monarchy but an aristocracy, because:

"[L]es sept Electeurs ont peu à peu retranché la souveraineté, ne laissant rien à

\footnotetext{
${ }^{347}$ A study of the Empire's last period of existence is obviously beyond the present study. For more details, see J.G. Gagliardo, supra, note 123, at $187 \mathrm{ff}$; and, J. Bryce, supra, note 26, at $359 f f$.

${ }^{148}$ It is important to point out that the Empire was not abolished by Napoleon but, rather, its dissolution was the result of Emperor Francis ll's renouncement to the Roman-German crown on 6 August 1806, following a note announcing that France no longer recognised the imperium which, in fact, amounted to an ultimatum for abdication; from then on, the authority of the Habsburg Emperor was limited to the Austrian borders - see J.G. Gagliardo, id., at 279-281; and J. Bryce, id., at 365-366. Therefore, it appears to be erroneous to refer to the Napoleonic abolition of the Holy Roman Empire, as some commentators did - see, for example, S.D. Krasner, supra, note 7, at 251, who wrote: "Napoleon abolished the empire completely in 1806."

i49. P. Guggenheim, "La souveraineté dans l'histoire du droit des gens - De Vitoria à Vattel," in Mélanges offerts à Juraj Andrassy (The Hague: Nijhorff, 1968), 111, at 114. Contra, see D. Philpott, "Westphalia, Authority, and International Society" (1999), 47 Political St. 566, at 574575, who opined: "Following Westphalia, only states exercised significant power, and they rarely forcibly interfered in one another's religious affairs. The Holy Roman Empire, by contrast, still enjoyed codified constitutional powers after 1648 , but states contemptuously ignored these powers: the Empire did not practice sovereignty in any meaningful way."

${ }^{150}$ See S.D. Krasner, supra, note 7, at 251-252.

51 See, generally, P. Schröder, supra, note 135.

152 J. Bodin, Les six Livres de la Republique (Paris: lacques du Puys, 1583), at 252. See also the translation by R. Knolles, The Six Bookes of a Commonweale (London: Impensis G. Bishop, 1606), at 184 .
} 
l'Empereur que les marques en apparence, demeurant en effect la souveraineté aux états des sept Electeurs, de trois cents Princes ou environ, \& des Ambassadeurs députés des villes Impériales. ${ }^{153}$

This opinion was shared by German authors like Hippolithus à Lapide (i.e. Bogislaw Philipp von Chemnitz), who argued forcefully against the exclusive power of the Emperor. ${ }^{154}$

Other 17 th century scholars tried to avoid a strict classification of ruling orders, which could obviously not match the multifarious German political reality. Therefore, Veit Ludwig von Seckendorf and Johannes Limnaeus suggested that the Emperor and the different constituting polities shared the supreme authority within the Empire. ${ }^{155}$ Samuel von Pufendorf also considered this issue shortly after Westphalia in his 1667 essay De statu Imperii Germanici, published under the pseudonym Severini de Monzambano. ${ }^{156}$ Influenced by Thomas Hobbes' Leviathan, ${ }^{157}$ he used the theory of

$153 \mathrm{~J}$. Bodin, $i d$., at 321 . [spelling modernised] Translated by R. Knolles, $i d$., at 236, as: "[T] seven princes Electors, having by little and little withdrawn the sovereignty, have left nothing unto the emperor, but the bare marks thereof in show; the sovereignty it self in effect remaining unto the state of the seven electors, of three hundred German princes or thereabouts, and the ambassadors deputed for the imperial cities." [spelling modernised] See also T.A. Walker, supra, note 18 , at 239.

It is also worth noting that Bobin summarily rebuked the pretensions of Imperial and/or Papal world overlordship later in his work - see J. Bodin, id., at $199 \& 201$; and, R. Knolles, id., at $135 \& 137$.

${ }^{54} \mathrm{H}$. à Lapide (i.e. B.P. von Chemnitz), Differtationem de ratione stats in Imperio noftro Romano Germanico (Argentorati: Josiae Staedelii, 1674).

${ }^{155}$ See P. Schröder, supra, note 135 , at 963.

${ }^{56} \mathrm{~S}$. de Monzambano (i.e. S. von Pufendorf), De statu Imperii Germanici (Utopiae: Vdonem Neminem, 1668). See the translation by E. Bohun, The Present State of Germany Written in Latin by the Learned Samuel Pufendorf under the Name of Severinus de Monzambano Veronesis (London: n.b., 1696).

${ }^{157}$ See T. Hobbes of Malmesbury, Leviathan, or The Matter, Forme, \& Power of a CommonWealth Ecclesiasticall and Civill (London: Green Dragon, 1651), at 115, who stated: "Having spoken of the Generation, Form, and Power of a Common-wealth, I am in order to speak next of the parts thereof. And first of Systems, which resemble the similar parts, or Muscles of a Body natural. By SYSTEMS; I understand any numbers of men joined in one Interest, or one Business. Of which, some are Regular, and some Irregular. Regular are those, where one Man, or Assembly of men, is constituted Representative of the whole number. All other are Irregular." [emphasis in original] [spelling modernised] See also N. Bobbio, Thomas Hobbes and the Natural Law Tradition (Chicago \& London: University of Chicago Press, 1993), at 180-181, footnote 11.

Pufendorf later elaborated on the question of the forms of political system in De jure naturae et gentium libri octo (Londini Scanorun: Adami Junghans, 1672); translated by B. Kennet, Of the Law of Nature and Nations, 3rd ed. (London: n.b., 1717), at 508, where he wrote that, "in order to completing the Essence of a just and regular State, such an Union is required as shall 
regular and irregular forms of polity - instead of the Aristotle's tripartite approach and concluded that the German constitutional form was monstrous, that is, of a hybrid nature between monarchical and aristocratic. ${ }^{158}$

For the purposes of the paper, the most meaningful facet of this examination of the Imperial institutions is that the Holy Roman Empire did not dissipate, neither in law nor in fact, as an aftermath of the Peace of Westphalia. ${ }^{159}$ As one historian appositely wrote: "The peace [in 1648] was not the tombstone of the empire but a charter which gave it another century-and-a-half of life." ${ }^{\prime 60}$ It follows that not only did Osnabrück and Münster fail to create a system of independent states, but the distinct separate political entities of Germany had to continue the fight to gain exclusive control and authority over their territory for long after Westphalia.

\section{Conclusion}

By way of conclusion, it is useful to recall the hypothesis set out at the start of the paper, namely that the Peace of Westphalia does not constitute a paradigm shift in the development of our state system. ${ }^{161}$ Rather, 1648 represents no more than one case where distinct separate polities pursued their unending quest for more authority through greater independence. Professor Hinsley once appositely wrote the following concerning the eagerness to ante-date the beginning of pivotal phenomena such as state-sovereignty:

make things which belong to the Government of it, seem to proceed from one Soul. Now hence it is manifest, that the former way of Mixture constitutes such a Body as is held together not by the Bond of one Supreme Authority, but barely by Compact; and which therefore is to be ranked, not amongst the regular, but amongst the irregular States." [spelling modernised]

${ }^{358}$ See E. Bohun, supra, at 154, at 152: "There is now nothing left for us to say, but that Germany is an Irregular Body, and like some mis-shaped Monster, if it be measured by the common Rules of Politics and Civil Prudence. So that in length of time, by the Lazy-easiness of the Emperors, the Ambition of the Princes, and the Turbulence of the Clergy or Churchmen, from a Regular Kingdom is sunk and degenerated to that degree, that is not now so much as a Limited Kingdom (though the outward Shows and Appearances would seem to insinuate so much) nor is it a Body or System of many Sovereign States and Princes, knit and united in a League, but something (without a Name) that fluctuates between these two." [emphasis in original] [spelling modernised]

It is important to note that, in 17th and 18th century writings, the term "monstrosity" - from monstrum in Latin - was used not as an insult to the Empire but, rather, to mean a striking and unusual irregularity in a political body; see P. Schröder, supra, note 135, at 966-967.

${ }^{159}$ For a succinct account of the main legal events on the international plane from 1648 to the beginning of the 20 th century, see A.S. Hershey, "History of Interntional Law Since the Peace of Westphalia" (1912), 6 American J. Int'l L. 30.

${ }^{160}$ R. Wines, "The Imperial Circles, Princely Diplomacy and Imperial Reform 1681-1714" (1967), 39 J. Modern Hist. 1 , at 2.

${ }^{161}$ See C. Weber \& T.J. Biersteker, "Reconstructing the Analysis of Sovereignty: Concluding Refiections and Directions for the Future Research," in T.J. Biersteker \& C. Weber (ed.), State Sovereignty as Social Construct (Cambridge: Cambridge University Press, 1996), 279, at 284. 
"Historians are liable to ante-date the completion of massive developments because of their preoccupation with origins. They are given to ante-dating the beginnings of massive developments for the same reasons and also because such developments are rarely finally completed: when the end of one phase is usually but the preliminary to the onset of the next it is easy to mistake the onset of another phase for the beginning of an entirely new departure. These opposite hazards have affected our assessments of the origin and evolution of the modern states' system. Only when due allowance is made for the first can it be seen that a new European states' system emerged in the eighteenth century, and not at an earlier date. Only when careful regard is paid to the second can it be seen that, for all the twists and phases it has recently undergone, the system which then emerged or finally matured in Europe is the system which still holds the world in its framework." 62

The above discussion attempted to substantiate this argument through a four-part chronological analysis. First, it was seen that the segmented and heteronomously organised medieval societies were based on decentralised feudal structures, which were later united as the Christendom under two transcendental political entities - the Pope and the Emperor. Secondly, the dynamics at work in Europe's religious and political spheres meant that, at the break of the Thirty Years War, the respective universal authorities of the Pope and the Emperor had already been severely depleted by the joint actions of the Reformation and the centralisation of government both within and without the Holy Roman Empire.

Thirdly, the principal objects and material provisions of the Osnabrück and Münster Treaties were shown to have been concerned with religious matters, territorial settlements and the formal transfer of a treaty-making power. Therefore, the purpose of Westphalia was certainly not the creation of independent polities, let alone independent states. On the contrary, it kept the imperium very much alive, be it in the Empire's institutions, through feudal territorial links, or with restrictions as regards alliances. Finally, it was seen that the Empire did not disappear in favour of the disparate German polities as an aftermath of the Peace. Indeed, despite a gradual reduction of function and power, the Imperial institutions remained until their dissolution in 1806.

As an epilogue, it is suggested to see the hypothesis as part of a wider argument concerning the semantics surrounding the concept of sovereignty. ${ }^{163}$ Indeed, the mythical

${ }^{362}$ F.H. Hinsley, Power and the Pursuit of Peace -- Theory and Practice in the History of Relations between States (Cambridge, Cambridge University Press, 1963), at 153. Linked to this idea of intertwined development periods, see A.B. Murphy, supra, note 63, at 109, who wrote: "If the history of state-territorial ideas and practices tells us anything, it is that changes in arrangements and understandings occur, but that no one era represents a radical break with the preceding era." [emphasis added]

${ }_{16.3}$ See H.J. Laski, The Foundations of Sovereignty and Other Essays (New York: Harcourt Brace, 1921), at 314, who once wrote: "Nothing is today more greatly needed than clarity upon ancient notions. Sovereignty, liberty, authority, personality- these are the words of which we want alike the history and the definition; or rather, we want the history because its substance is in fact the definition." Recently, B. Boutros-Ghali, "Empowering the United Nations" 
character of the Westphalian model would fall within the following contention: the idea (perhaps even the $i_{\text {deal }}{ }^{164}$ ) of distinct separate corporate-like polities enjoying supreme and exclusive control and authority over a relatively well-defined territory, which is nowadays associated with the term sovereignty, constitutes a subjective construct of consciousness fulling social functions and changing over time. ${ }^{165}$ A further metaphysical analysis of sovereignty and our present state system is beyond the scope of the present paper but would no doubt confirm the resolving nature of Westphalia as an idea-force. ${ }^{160}$

(1992-93), 71 Foreign Affairs 89, at 99, expressed the following view: "A major intellectual requirement of our time is to rethink the question of sovereignty - not to weaken its essence, which is crucial to international security and cooperation, but to recognize that it may take more than one form and perform more than one function."

364 The "imprecise word" idea was defined by Philip Allott as "a bringing-together of units of consciousness which has an effect within consciousness greater than the sum of the effects of the individual units which it contains," while ideal would mean "what reality should be the ideal);" see P. Allott, supra, note 34, at 14 \& 190. [emphasis added] In fact, according to the Allottian view, the notion of ideal has two equally important dimensions, namely (i) the premise that by changing ideas we can change reality, and (ii) the ambition that by changing things we can create a better future.

${ }^{365}$ Indeed, words encapsulating concepts such as sovereignty represent human "consciousnesscreating-consciousness" aimed at fulfilling some general or specific purpose, and in a particular time and space ceaselessly changing. Philip Allott, id., at 8, put it as follows: "The meanings of our words determine their practical utility to us, the uses to which we may put them within the continuing process of consciousness." As it was recently put by J.S. Barkin \& B. Cronin, "The State and the Nation: Changing Norms and the Rules of Sovereignty in International Relations" (1994), 48 Int'l Org. 107, at 109: "It is often not appreciated fully that sovereignty is a social construct, and like all social institutions its location is subject to changing interpretations. In other words, while the specific expression of sovereignty may remain constant, that which is considered to be sovereign changes." [emphasis added]

366 On ideas, idea-acts and idea-forces, in the context of self-determination, see P. Allott, supra, note 33 , at $185 \& 188$. The terminology of $i d e a-f o r c e$ is borrowed from a general doctrine found in philosophy - see A. Fouillée, L.'évolutionnisme des idées-forces (Paris: Félix Alcan, 1890), at XI, who wrote: "Si nous avons adopté cette expression très générałe d'idée-force, c'est précisément pour y envelopper tous les modes d'influence possible que l'idée peut avoir, en tant que facteur, cause, condition de changement pour d'autres phénomènes, etc., en un mot toutes les formes d'efficacité quelconque, par opposition aux idées-reflets, aux idées-ombres qui n'entrent pour rien dans le résultat final et n'en sont que des symboles ou des aspects." [emphasis in original] See also A. Fouillée, Morale des idées-forces (Paris: Félix Alcan, 1908). 